\title{
Innovation in the public sector in a small open economy-initial investigation of patent activity at the Czech universities
}

\author{
Petra Maresova * D, Ivan Soukal, Ruzena Stemberkova and Kamil Kuca
}

\author{
*Correspondence: petra.maresova@ \\ uhk.cz \\ Faculty of Informatics and \\ Management, University of Hradec \\ Kralove, Rokitanskeho 62, 50003 \\ Hradec Kralove 3, Czech Republic
}

\begin{abstract}
For a successful economy, the interaction between research and its application in practice plays a key role. The aim of this paper is to analyze the institutional factors of patent activity at universities in the Czech Republic. The following five factors were selected for detailed investigation: budget from government, number of employees: professors, associate professor, and assistant professor, number of researchers and other employees, number of students (PhD, master, and bachelor), technology transfer workers. The patent activity analysis used methods of retrospective data analysis in the field of R\&D activities, unstructured interviews, and statistical data processing. Following from the basic characteristics of the collected data, patent activity is related to the nature of universities, where technical universities are in leading positions in the monitored period of industrial-legal protection. However, the importance of encouraging innovation activity across all disciplines is crucial. The result of monitoring the dependency shows that a relationship of efficiencies and patent output is influenced by the size of a university. Secondly, there can be observed that technology transfer efficiency contributes more to the patent output that research staff efficiency.
\end{abstract}

Keywords: Patent activities, Factors, Universities, Regression analysis, Czech Republic JEL: O12, O 20, M10, H41

\section{Introduction}

The competitiveness of economies depends on the ability to create new technologies and use them to create new products and innovative solutions (Drumea \& Mirela, 2015). Global issues, such as environmental challenges, can be most efficiently tackled when applied research is promoted by revenue received from licensed intellectual property. In this respect, a major role is played by universities, especially in terms of access to intellectual property and an institutional support of this process. Should they succeed in this highly competitive field, the universities must seek collaboration opportunities with leading institutions, foundations, and companies involved in research. Such collaboration proves highly beneficial in building a bridge between theoretical research and its practical application and, above all, it unlocks additional funding options

(c) The Author(s). 2020 Open Access This article is licensed under a Creative Commons Attribution 4.0 International License, which permits use, sharing, adaptation, distribution and reproduction in any medium or format, as long as you give appropriate credit to the original author(s) and the source, provide a link to the Creative Commons licence, and indicate if changes were made. The images or other third party material in this article are included in the article's Creative Commons licence, unless indicated otherwise in a credit line to the material. If material is not included in the article's Creative Commons licence and your intended use is not permitted by statutory regulation or exceeds the permitted use, you will need to obtain permission directly from the copyright holder. To view a copy of this licence, visit http://creativecommons.org/licenses/by/4.0/. 
for young and established researchers alike to pursue their work on foundational projects. A collaboration between academic institutions and business companies allows for a free flow of possibly ground ideas between the two sectors and creates an optimal environment for developing much-needed solutions to global challenges. Discussing the situation in Europe, Likeschova et al. (2013) confirm the crucial importance of the academic and the business world working together towards a common goal. Balancing the requirements of research publication on the part of the universities and research commercialization on the part of the businesses however presents a complex challenge (Ambos et al., 2008; Chang et al., 2009), which is being approached from different perspectives.

The Czech Republic is a developed country that is ranked among the most developed economies of the world in the statistics by the United Nations, the International Monetary Fund, and the World Bank (International Monetary Fund, 2017). The Czech Republic is characterized by a relatively small internal market, uncomplex natural resources, and a relatively high level of industrial development. In view of these characteristics, the Czech Republic belongs to a group of countries where the high degree of economic openness toward the external environment is typical. Based on theoretical and empirical findings, the degree of openness should be positively correlated with the degree of economic development and negatively with the size of the economy. For the Czech Republic, patent activity is therefore essential (Zdralek et al., 2016).

Therefore, this paper undertakes to analyze selected institutional factors that influence the patent activity at Czech universities. Ten selected variables are analyzed: budget from government, number of employees: professors, associate professor, assistant professor, number of researchers and other employees, and number of students ( $\mathrm{PhD}$, master, and bachelor), technology transfer workers. The analysis uses a combination of methods, including statistical data processing, retrospective analysis of data pertaining to the $R \& D$ area, and unstructured interviews. The above-listed institutional factors were chosen because of their proven high relevance to the topic, which is confirmed by numerous published research studies (Gür et al., 2017; Chang et al., 2016) as well as statements issued by influential institutions, such as WIPO and OECD (WIPO, 2008; OECD, 2014; Industrial Property Office Czech Republic, 2015), state governments, and global companies involved in patent activities (McKinsey, 2013). To name but one example, Sanberg and McDevitt (2013) points out the revolutionary impact of the 1980 Bayh-Dole Act, which granted US universities the right to hold on to intellectual property funded from the federal budget. This change affected a shift in the academic circles toward a more entrepreneurial mindset and, in the long run, generated greater licensing income, whose volume increased as a result of new collaborations and new funding opportunities. It follows that funding and budget options significantly affect patent activity. In his study, Wu et al. (2015) examines both individual and institutional factors influencing the area of patents. The individual factors include the participation of industry scientists in the research, additional research activities performed at the stage of the patent review, and the investors' attitudes concerning the commercialization of research. Among the institutional factors are perceived Technology Transfer Office's (TTO) service effectiveness, cost-saving measures, and patenting fee coverages, and license owner's requirements prior to patent application. These findings evidence the major role of TTO in funding. Furthermore, Melendez \& Moreno's 
(2012) research concludes that the existence of TTO increases the engagement of researchers and improves their involvement in the knowledge transfer exchange (KTE) and open innovation (OI) processes. Finally, Wu et al. (2015) indicates that universities with a functioning and cost-effective TTO are more likely to be granted a license for their inventions. Based on these findings, this paper focuses primarily on Czech universities with a favorable environment in terms of patenting, which is the majority of universities in the Czech Republic. Institutional factors selected for a close examination include those variables which are directly or indirectly related to budget and funding.

\section{Methods}

\section{Sample description}

In the Czech Republic, there are a total of 26 public universities which are established under a special law. Their competences are specified in Act No. 111/1998 Coll., on universities and also on changes and amendments to other laws, and are determined by the Ministry of Education, Youth, and Sports. Out of these 26 public universities, 15 of them were chosen for analysis, in which there is a provision of a technology transfer office.

\section{Data collection}

The patent activity analysis used the method of retrospective data analysis in the field of R\&D activities as well as internal documents and measures of individual universities in the Czech Republic relating to the protection and management of intellectual property. Internal documents were analyzed in June 2019 and data was updated. The following quantities are selected as possible predictors: budget from government, number of employees: professors, associate professor, assistant professor, number of researchers and other employees, and number of students ( $\mathrm{PhD}$, master and bachelor), technology transfer workers. Furthermore, unstructured interviews were conducted with a representative from the Ministry of Education, Youth, and Sports in Prague and the heads of technology transfer centers. Within the reported period, which spanned between March to June 2016, a total of 11 unstructured interviews took place. Universities with an already established office of technology transfer were selected for detailed examination, i.e., those universities which already have previous experience in the development of the third role of universities. A questionnaire survey was carried out among these universities.

\section{Research instruments}

Nevertheless, with the reduction of candidate predictors, the number of observations is relatively small. Instead of one all-including linear model, there was a chosen different approach. The first was to assess variables as a possible predictor. Then assess the ratio, especially ratio related to efficiency, i.e., staff per one patent. In addition, the method of searching for the most suitable submodel using Akaike information criterion with correction was employed. The quality of individual submodels were assessed using AICC (Hurvich \& Tsai, 1989). In addition to these indicators, variance analysis in regression was used. Apart from the significance and the coefficient directive, the SPSS has its own indicator of the meaning of a given variable. This indicator is based on the 
significance of the predictor for the overall model by comparing the sum of the squares of the residues when the predictor is removed from the model.

\section{Results}

\section{Characteristics of Czech economy and patent activity}

Characteristics of Czech economy. The main drivers of the economy in the Czech Republic are foreign companies, both directly by their performance and indirectly by generating an extensive demand for the production of endogenous companies. These companies represent the main actors that involve the Czech Republic in European economy and by extension in the world economy. Foreign company branches as a whole reach significantly faster productivity and export growth rates than the endogenous corporate sector. At the same time, they are the main source of transfer of advanced technology, management methods, and other proven practices, such as innovation management, in the Czech Republic, thus strongly contributing to the growth of local economy productivity. The high dependence of the domestic economy on the activities of foreign companies is evidenced by the development of the current account balance and structure. While in 1996, the trade balance deficit still constituted 9.2\% of GDP, in just 10 years it developed into a surplus currently amounting to $5 \%$ of GDP. The speed and extent of the trade balance development clearly points to external causes. From the point of view of the smart specialization strategy, two significant problems are associated with the above-mentioned economic development. Firstly, strategic decisions of a large proportion of companies regarding their future direction are implemented outside the Czech Republic. A significant space for innovation is available for the application of new technologies in traditional fields. Traditional industries are precisely where a large proportion of medium-sized and large endogenous enterprises operate. Productivity and export performance in foreign-controlled companies significantly exceeds the levels of both indicators in endogenous companies. The companies differ in their decision-making autonomy, most are limited in terms of strategic responses to new business opportunities and risks. Furthermore, most of the foreign companies in the Czech Republic fulfill only some business functions. Most often, this involves ensuring production, assembly, and logistics between the production plant and warehouses in the Czech Republic and abroad, which are activities with the lowest share in the total added value of products and services on the market. Although a number of manufacturing companies are gradually introducing development and other engineering activities, most strategic activities at the beginning of value chains and business activities at their end are implemented outside the Czech Republic. It is in these activities where most of the total value of products and services is concentrated and where strategic decisions concerning the direction of the innovation process of these companies are made (National RIS3 strategy, 2014). It follows from the above that patents, innovation, and technology transfer are a key issue for the Czech Republic as an open economy.

Characteristics of patent activity. As discussed above, the provision of support to innovation activities from public sources is essential for an efficient functioning of the economy and strengthening the state's competitiveness (Treaty on the Functioning of the European Union, hereinafter TFEU). Innovation policy is one part of general state 
policy. And there is also some interconnection between public support for research, development, and innovation and general public support. Although the number of empirical studies dealing with the impact of public support for innovation is increasing, the results are still mixed (Bronzini, Piselli, 2014). Kincl (2004) specifies that it is a question not only of state resources but also of funding coming from regional and local governments. In the case of the Czech Republic, these are ministries, other central state administration bodies, regions, cities, and municipalities. State funding can also be provided by state funds, legal entities under a direct or indirect control of the state or of self-governing corporations, and private legal entities authorized to redistribute public funds (Kincl, 2004).

The Czech Republic performs poorly in terms of patent activity when compared to other European Union members. The 2012 Eurostat data give the number of 2.09 per million inhabitants in the $28 \mathrm{EU}$ countries, but only 0.32 in the Czech Republic (Eurostat, 2016). The distribution of patents filed in the last decade is shown in Table 2. In 1990, the total number of filed patents was approximately 88 and the number of universities undertaking innovation was only 6 . What is more, there was a decline in the years after that, continuing up to 2006, when a total of 98 patent applications were registered by 14 universities. Following 2006, there was an increasing tendency. The year 2012 was the most fruitful one, with 796 patent applications filed by 18 universities. Table 1 indicates that there are significant differences among universities in terms of patent activity. This leads to the question: What determines patent activity at universities? (Table 1).

Table 1 illustrates that patent activity varies considerably at different universities. This brings us to the next question of this paper: What determines the number of patents in universities?

\section{Sample characteristics}

Table 2 shows collected data for 11 universities and 10 selected variables: budget from government, number of employees: professors, associate professor, assistant professor, number of researchers and other employees, and number of students $(\mathrm{PhD}$, master and bachelor), technology transfer workers. For ease of comparison, Table 1 also includes the number of patents. These are patents granted in the Czech Republic. In the Czech environment, it is often the case that universities do not have sufficient funds for a foreign application of their patents. International patent protection is then usually implemented in cooperation with companies within 12 months of filing a national application, when a given commercial partner actively searches for the technology with a clear interest in selling the product abroad, so that the state or region for filing the patent application is chosen according to the interests of the business partner. The selection includes both universities with fewer staff, researchers, and budget, which may include the Technical University of Liberec, University of Pardubice, University of Hradec Kralove, and the University of West Bohemia, as well as universities with several large budgets and workplaces: Masaryk University, Charles University, and Brno University of Technology.

\section{Analysis of the patent activity determinant}

Various variable subsets were studied to find predictors of the patent output. From the very beginning there was a clear presence of a certain ambiguity in the data. 
Table 1 Distribution of filed patent documents in the last 10 years

\begin{tabular}{|c|c|c|c|c|c|c|c|c|c|c|c|c|c|}
\hline & Year & 2017 & 2015 & 2014 & 2013 & 2012 & 2011 & 2010 & 2009 & 2008 & 2007 & 2006 & 2005 \\
\hline University & Total & & 97 & 353 & 697 & 796 & 665 & 522 & 352 & 288 & 142 & 98 & 54 \\
\hline $\begin{array}{l}\text { Czech Technical } \\
\text { University in Prague } \\
\text { (CTU) }\end{array}$ & 1126 & $x$ & 25 & 65 & 185 & 136 & 136 & 116 & 82 & 81 & 43 & 39 & 29 \\
\hline $\begin{array}{l}\text { Czech University of Life } \\
\text { Science Prague (CZU) }\end{array}$ & 472 & 25 & 3 & 15 & 30 & 200 & 88 & 58 & 46 & 18 & 6 & 5 & 2 \\
\hline $\begin{array}{l}\text { University of South } \\
\text { Bohemia in České } \\
\text { Budějovice }\end{array}$ & 137 & 7 & 4 & 5 & 9 & 8 & 20 & 14 & 27 & 25 & 9 & 6 & 4 \\
\hline $\begin{array}{l}\text { Mendel University in Brno } \\
\text { (MENDELU) }\end{array}$ & 205 & $x$ & 16 & 22 & 36 & 26 & 57 & 19 & 11 & 10 & 1 & 3 & 0 \\
\hline Masaryk University (MU) & 106 & 9 & 0 & 17 & 18 & 16 & 21 & 9 & 6 & 4 & 3 & 1 & 3 \\
\hline University of Ostrava & 6 & $x$ & 0 & 0 & 1 & 0 & 1 & 2 & 2 & 0 & 0 & 0 & 0 \\
\hline $\begin{array}{l}\text { Technical University of } \\
\text { Liberec (TUL) }\end{array}$ & 396 & 29 & 13 & 38 & 71 & 63 & 76 & 60 & 36 & 15 & 10 & 5 & 2 \\
\hline $\begin{array}{l}\text { University of Hradec } \\
\text { Kralove (UHK) }\end{array}$ & 17 & 3 & 0 & 0 & 2 & 6 & 4 & 4 & 0 & 1 & 0 & 0 & 0 \\
\hline $\begin{array}{l}\text { Jan Evangelista Purkyně } \\
\text { University in Ústí nad } \\
\text { Labem (UJEP) }\end{array}$ & 14 & $x$ & 0 & 1 & 2 & 2 & 4 & 0 & 0 & 1 & 2 & 1 & 1 \\
\hline Charles University & 163 & 17 & 1 & 11 & 28 & 21 & 18 & 22 & 20 & 20 & 6 & 6 & 0 \\
\hline $\begin{array}{l}\text { Palacký University } \\
\text { Olomouc }\end{array}$ & 154 & 15 & 9 & 7 & 24 & 17 & 8 & 26 & 14 & 17 & 9 & 8 & 1 \\
\hline University of Pardubice & 52 & 5 & 0 & 2 & 10 & 6 & 6 & 5 & 4 & 5 & 8 & 4 & 0 \\
\hline $\begin{array}{l}\text { Tomáš Baṫa University in } \\
\text { Zlín }\end{array}$ & 168 & & 2 & 21 & 32 & 36 & 25 & 19 & 13 & 17 & 2 & 0 & 0 \\
\hline $\begin{array}{l}\text { University of Veterinary } \\
\text { and Pharmaceutical } \\
\text { Sciences Brno }\end{array}$ & 17 & $x$ & 0 & 0 & 5 & 3 & 8 & 1 & 0 & 0 & 0 & 0 & 0 \\
\hline $\begin{array}{l}\text { Technical University of } \\
\text { Ostrava (VŠB) }\end{array}$ & 354 & 33 & 9 & 62 & 41 & 61 & 52 & 72 & 19 & 24 & 4 & 5 & 1 \\
\hline $\begin{array}{l}\text { University of Chemistry } \\
\text { and Technology in } \\
\text { Prague }\end{array}$ & 407 & $x$ & 3 & 32 & 37 & 73 & 34 & 26 & 16 & 13 & 0 & 6 & 8 \\
\hline $\begin{array}{l}\text { Institute of Technology } \\
\text { and Business in České } \\
\text { Budějovice }\end{array}$ & 42 & $x$ & 0 & 3 & 11 & 14 & 2 & 2 & 4 & 6 & 15 & 0 & 0 \\
\hline $\begin{array}{l}\text { Brno University of } \\
\text { Technology }\end{array}$ & 463 & 25 & 9 & 44 & 111 & 63 & 56 & 52 & 34 & 26 & 20 & 8 & 3 \\
\hline $\begin{array}{l}\text { The University of West } \\
\text { Bohemia }\end{array}$ & 194 & 30 & 3 & 8 & 44 & 45 & 49 & 15 & 18 & 5 & 4 & 1 & 0 \\
\hline
\end{tabular}

Source: Zdrálek et al. (2016) and own

Ambiguous results were found regarding in general most promising and the most frequently mentioned predictor by the literature-a total count of technology transfer workers, see Fig. 1 below.

Therefore, a different approach was taken. A question of efficiency and rations balance was studied concerning mentioned most frequently used predictor of a total number of transfer of technology of workers. Figure 1 suggests that there is a significant technology transfer efficiency discrepancy. A very close linear correlation can be seen on the chart below. The total patent output linearly drops as the ration of technology transfer workers needed per one patent increases. 


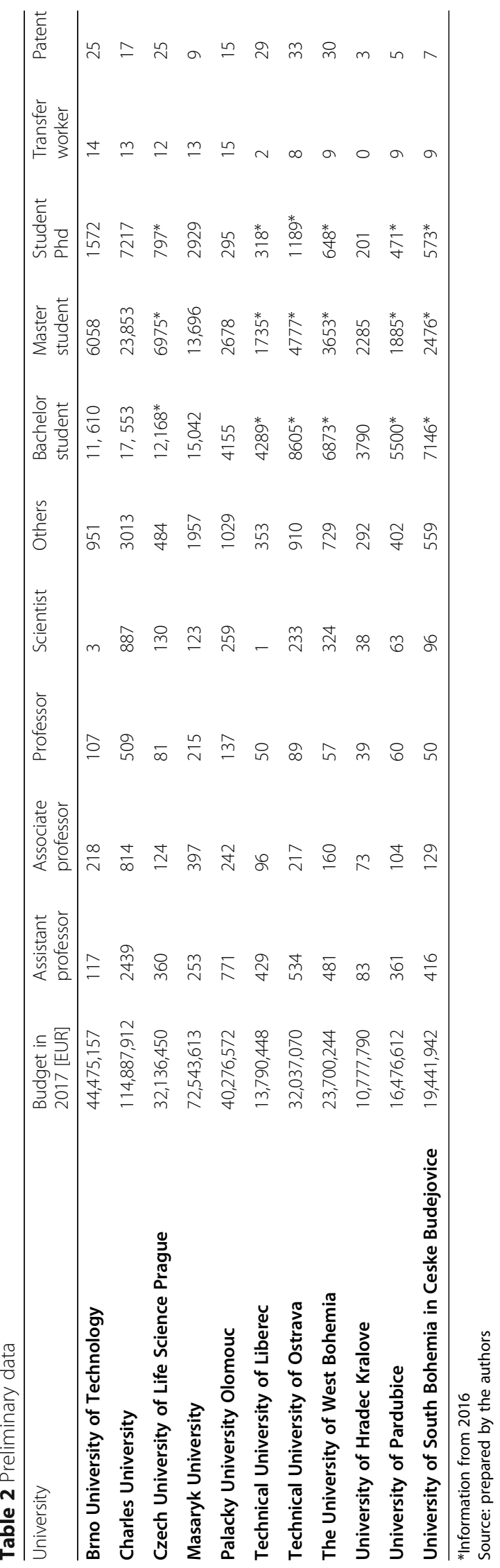




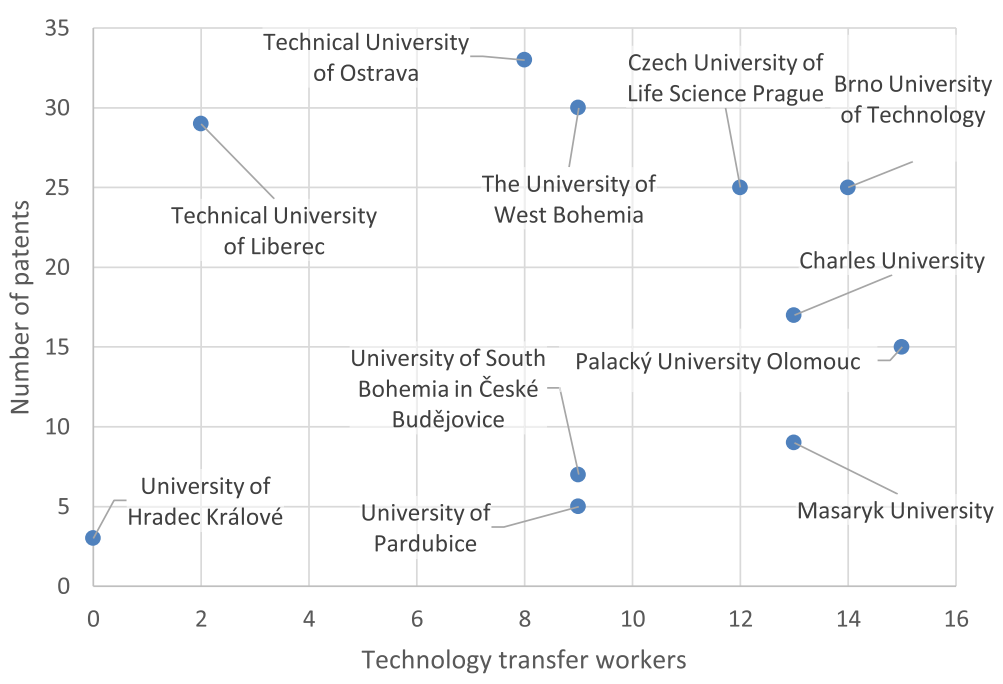

Fig. 1 Ambiguous results related to transfer workers number

The chart shows that technology transfer workers efficiency has significant impact with a regression function $y=-17.287 x+33.236$, the zero-point hypothesis test $p$ value was over a level of significance. Even small decrease of efficiency, i.e., increase of needed technology transfer workers per one patent, harms the total patent output. A linear function is highly fitting described by a very high determination index $R^{2}=0.93$. Technical University of Liberec shows a peak performance in terms of both the total patent output and efficiency. It is matched by only two much larger and better funded universities from Ostrava, and from Pilsen (University of West Bohemia). The largest and the best funded Charles University shows a mediocre result and on the bottom of the efficiency and total output can be found University of Pardubice along with the second largest and the second-best funded Masaryk University.

Following the idea of the most usual variables, we studied influence of master students, Ph.D. students, and a budget. This was confirmed by a best-subset-based linear modeling. The best AICC values were present in a model based on three predictors: master's degree students, doctoral degree students, and budget. The amount of the budget and its impact has not been proven statistically significant. This may be also due to the fact that the analysis used the entire budget which is allocated to universities especially in relation to the number of students. In a further analysis, attention should be focused purely on the part of the budget related to scientific results. The number of $\mathrm{PhD}$ students was found positive and statistically significant on the patent activity of the university. This finding corresponds to the situation of successful fast-growing universities abroad. An example is UTM Malaysia (UTM, 2019) which stands out for its year-to-year improvement of its position in the international rankings and its extremely high share of PhD students. Yet, the model itself could not be acknowledged due to the last variable of master's students. Its influence was calculated with a negative slope. That in general, cannot be accepted; however, this is a proof of patent-unrelated influence from the faculties with a very high number of students. Please see the "Discussion" section for a further explanation since the formula cannot be interpreted in a standard manner. The model equation was the number of patents $=23.3-0.011 \times$ master's 
students $+0.034 \times \mathrm{PhD}$ students adjusted determination coefficient of $54.8 \%$. The zeropoint hypothesis test of the regression line directive showed a statistically significant difference with a $p$ value of 0.36 .

Furthermore, we studied a ration relation further and the efficiency in research. Research efficiency was defined as the total number of research staff per patent. The research staff counts in assistant professors, associated professors, professors, scientists, and $\mathrm{PhD}$ students since $\mathrm{PhD}$ students were already proven with a positive relationship in a previous model, and since they have to display a certain scientific performance in order to remain a PhD student or better to successfully obtain the title. Technology transfer efficiency was set in the same manner as in Fig. 2.

Unlike the transfer efficiency the research efficiency shows non-linear relationship characterized by regression function $y=0.0002 x 2-0.1807 x+35.554$ and an index of determination $R^{2}=0.71$. If two largest universities by students and funds would be removed a straight and fitting linear trend would have appeared. There can be again observed three top-performing universities from Liberec, Ostrava, and Pilsen (University of West Bohemia). Then as the research staff efficiency drops that can be found a braking point where synergy and budget effects in large universities can take place increasing the patent output again.

Finally, we conducted an efficiency comparison to examine universities and to explore the relation to the total patent output (Fig. 3).

The chart shows that the highest output is naturally found in universities with both research and technology transfer efficiency. Then the sample shows again a non-linear relationship mainly due to two largest and best-funded universities: $y=-7 \mathrm{E}-06 \mathrm{x} 2+0.0057 \mathrm{x}$ +0.0338 with an index of determination $R^{2}=0.70$. Without the Masaryk University and Charles University in the sample a linear trend up to a certain point would be fitting. However, without such modification there can be observed that after a certain size the relationship of efficiencies and patent output is influenced by the size of a university. Secondly, there can be observed that technology transfer efficiency contributes more to the

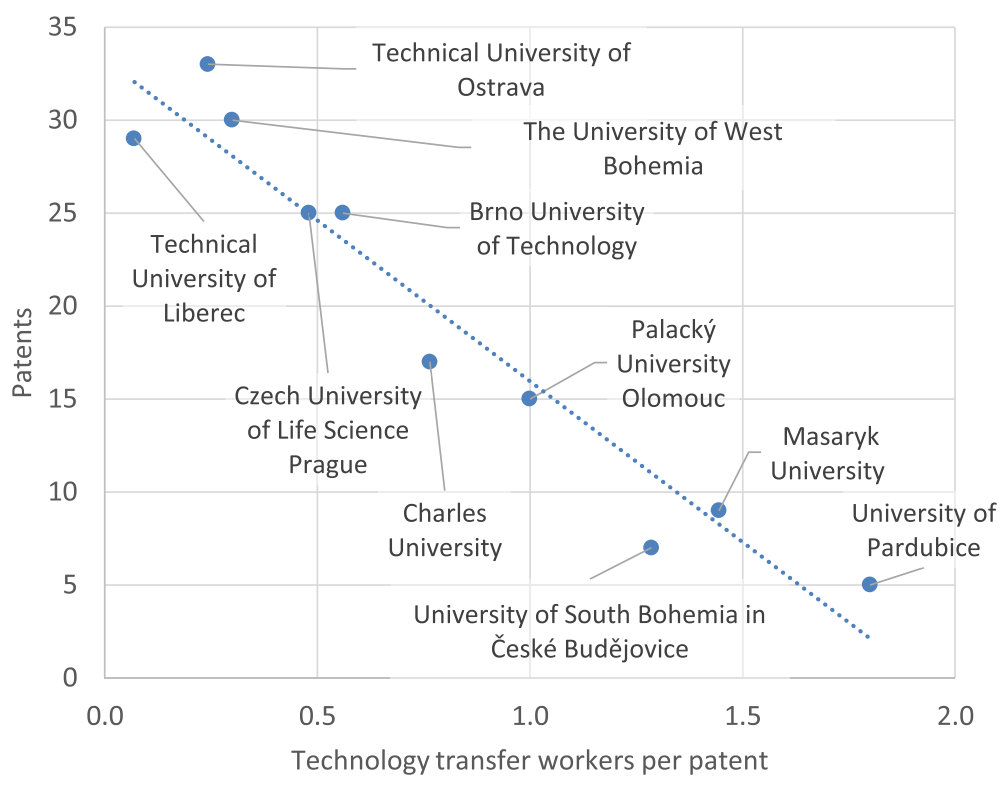

Fig. 2 Technology transfer workers efficiency impact on total patent output 


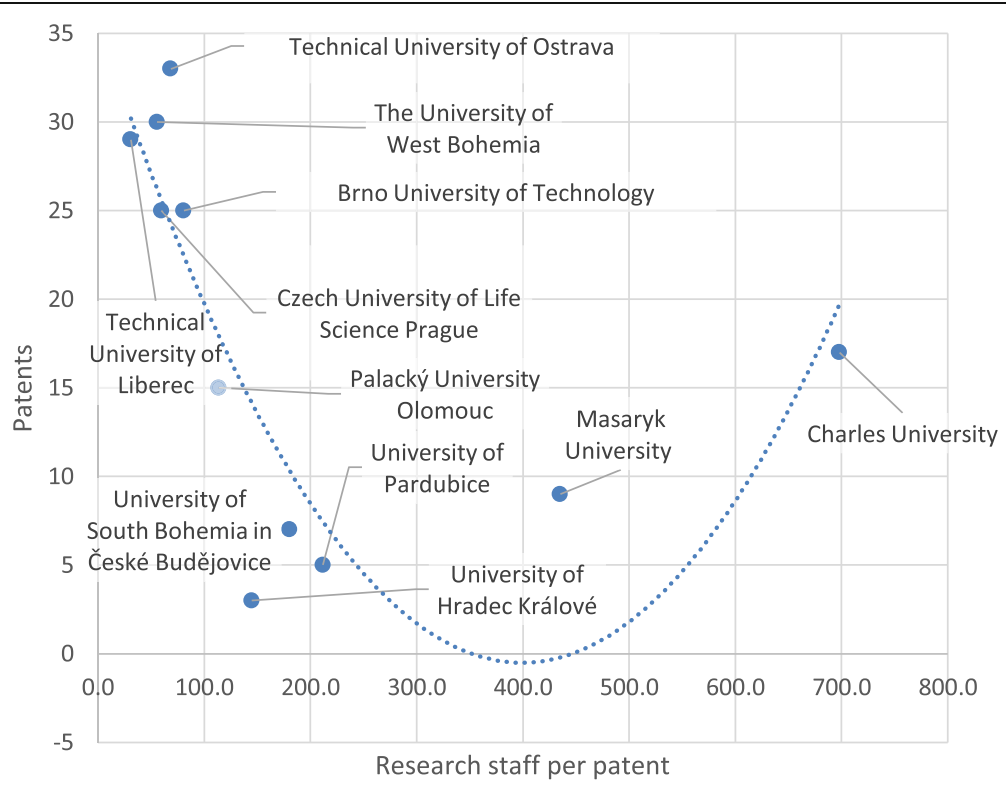

Fig. 3 Research staff efficiency impact on total patent output

patent output that research staff efficiency. In the simplest economic point of view, marginal technology transfer worker could improve total patent output much more than one marginal, i.e., additional research worker. Of course, this cannot be generalized and it is valid up to a certain point as can be seen in the charts of efficiency (Fig. 4).

\section{Discussion}

Patent activity is related to the nature of universities, which explicitly follows from Table 2. This finding points toward the assumption that mostly technically oriented

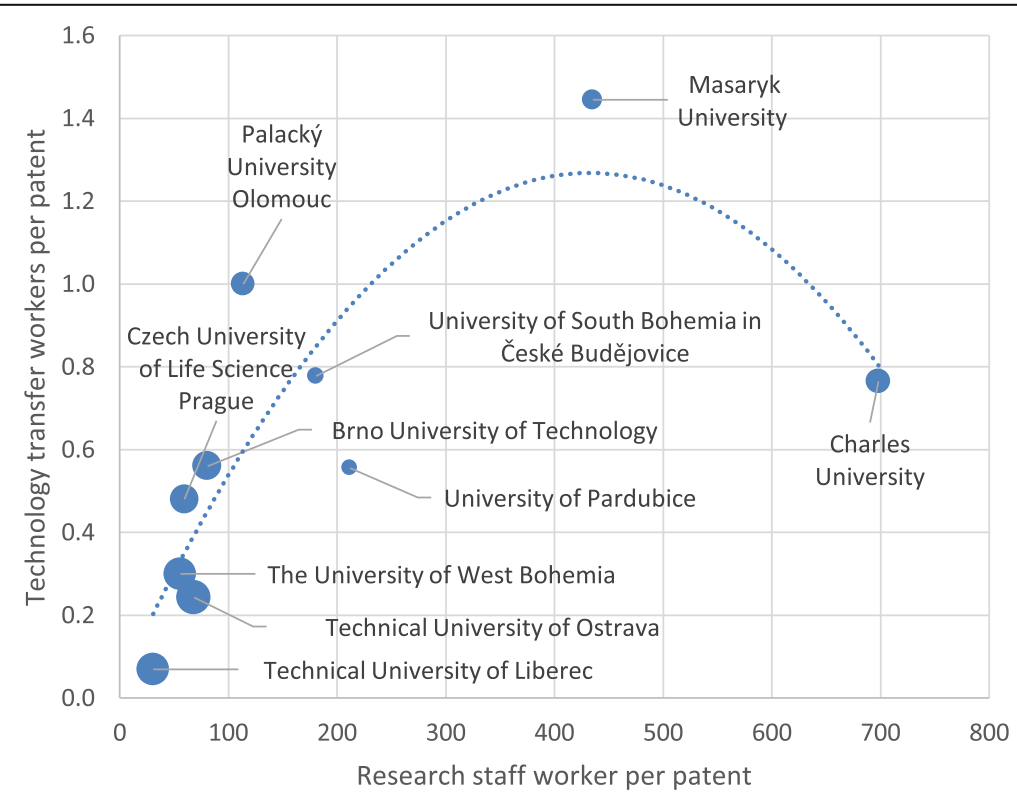

Fig. 4 Research and technology transfer efficiency influence on the total patent output 
universities develop a higher patent activity than others and university with a higher number of $\mathrm{PhD}$ students are also more active. This assumption could be tested by dividing the sample of universities according to the specializations of their faculties. However, this approach would be difficult to execute because of the complexity of processes concerning patent documentation in the Czech Republic. In the Czech Republic, there is a universal system of intellectual property protection in effect, which does not take into account the individual faculties, so that patents are registered at the Czech Office of Industrial Property by the name of the university, not faculty. Furthermore, the data collected from the conducted unstructured interviews show that some researchers, particularly at regional universities, oscillate between different faculties of the same university or are responsible for interdisciplinary subjects. These are often researchers who tend to bring innovative ideas, hence developing important inventions. That is another reason why analyzing the patent activity of individual faculties is not likely to bring any relevant results. Furthermore, it is common for universities to undergo restructuralization in 10- to 20-year intervals, which means that the structure of the university faculties, departments, and institutes may change entirely over the course of time.

Regarding the analysis, we identified a significant efficiency discrepancy regarding the technology transfer worker performance. Such a magnitude of discrepancy cannot be explained by a mere fact of different university structure. A presence of higher ratio of social sciences or humanities-oriented faculties does not influence the result. Plainly speaking, if such faculties do not create patents, they do not need any technology transfer workers at all. Hence, only patent creating faculties and universities' internal processes influence this ration. Then a general explanation of having a lot of patent unrelated faculties which drags a patent evaluation down is not valid, e.g., Masaryk University. Yes, there can be an objection that a leadership and personal abilities of university management can influence a patent output more than an average technology transfer worker output. Such case is the Technical University of Liberec which with a great help of its vice-dean outperformed larger, better funded and well-established universities. However, even without this hidden correlation or rare case the results in Table 2 shows a fitting linear trend that cannot only be a result of university management leadership. If this effect should be proven as a factor of the analysis a longer time-series would have to be studied, one more variable and partial regression would have to be employed.

The regression-model comment is needed for mostly concerning the master degree student's slope. From mathematical point of view in a current dataset, it cannot be distinguished as the universities structure. There are large universities such as Charles University or Masaryk University with a lot of students who are attending social science and humanities faculties. Such faculties are not those where a patent creation can be expected such as engineering or natural sciences ones. On the other side, there is a small but highly efficient Technical University of Liberec with high patent output. Then in a regression from the mathematical point of view, it seems that a lower number of magister students lead to a better patent output but that is incorrect. The correct interpretation would be that lower share of patent-unrelated faculties' students leads to a greater patent output when the number of university students remains the same.

Unfortunately, in most of the study the University of Hradec Kralové could not be incorporated since they employed no technology transfer staff at that time. Therefore, 
technology transfer efficiency would be dividing the index by zero and so it had to be excluded.

It must be noted that there are some limits that may have had an impact on the outcome. The result and the model were significantly affected by the size of the sample, which does encompass a large proportion of the population surveyed, however, the population is very small in itself. Models with predictable variables, such as the number of employees in technology transfer offices, the number of researcher employees, and the number of professors, were not conclusive in which the hypothesis of the non-zero slope of the regression line was not rejected. At the same time, these models reached very low values of the adjusted determination coefficient.

Patent activity is influenced by a large number of factors. As recent research shows, the complex interplay of factors includes not only the universities' characteristics but also public policy at the country or the regional level, economic and social characteristics, and technological level. For example, the Triple Helix Model proposed by Etzkowitz and Leydesdorff (2000) examines the interconnection of universities, industry, and government. Huggins argues that the open innovation system brings to the fore regional assets in the innovation processes. Carayannis and Campbell (2006), authors of the Quadruple Helix model, underline the role of the media- and culture-based public. The result is a gradually emerging organic system of knowledge and innovation, wellsuited to knowledge-based economy. Given the shift from the traditional linear innovation process toward "iterative chain-link models based on the interaction between knowledge actors" Huggins \& Johnston, (2012), the role of the region gains in importance. Laperche demonstrates that the commercialization of public research is the results of an "organic paradigm" of four interrelated factors: university strategy, legislation, economic environment and entrepreneurship, and technical progress. This theory is ultimately supported by the data in Table 1 . As to the exact numbers capturing the patent activity of public universities in the Czech Republic between years 2005 and 2015, Table 1 illustrates that the patent activity drops significantly at the turn of 2013 and 2014. This decline concerns in most public research institutions, and, in many cases, it is a sharp decline, which also affects technical universities. It transpired from the conducted interviews that this trend was caused by the change in financial compensation policies for RIV points allocated to patents. The universities were originally allocated funds based on the above RIV points, which represented individual predefined results, for which the Ministry of Education provided financial rewards to universities in the calendar year budget. According to the new policy, points are no more allocated to each patent but only to licensed patents.

Risks involved in the analysis carried out and the results obtained lie in the exclusion of any other variables that also affect the patent practice. This could include specifications of the amount of funding for science, the nature of research projects, or financial rewards awarded to patent originators and other regional factors, as stated, for example, by Etzkowitz and Leydesdorff (2000) above. Furthermore according to Žížalová et al. (2011), the main features of the incentive system of employees include the proportion of income from commercialization, bonuses, provision of adequate equipment required for R\&D activities, and academic career building (Žížalová et al., 2011). These motives are also confirmed in many studies conducted abroad (Zain et al. 2011; Livotov, 2015). Other researchers, namely Kand and Sohn (2016), proposed new indices that can be 
used to evaluate the patenting activities of R\&D organizations. An exploratory factor analysis (EFA) is used to identify three indices: the forward citation, impact per unit time, and patent family factors (Kang \& Sohn, 2016). Lo (2012) shows that the university administrations took very proactive roles in patenting the research inventions or works that resulted from the university-funded research after two Bayh-Dole-like acts were passed in Taiwan.

There follow two possible approaches for future research-one is a more detailed specification of the financing of patent activities. Another way of approaching the data is to enlarge the sample of surveyed universities with the simultaneous extension of the variables in the context of regional conditions.

\section{Conclusion}

The Czech economy is now in a stage where it is gradually losing its advantage of price competitiveness, especially in manufacturing, which is due to the domestic growth in the price of labor, energy, and services, and is furthermore compounded by the growth in attractiveness of conditions for locating certain types of activities in emerging countries. This loss of competitiveness so far concerns only some types of activities or fields, but it is likely that the trend will continue to expand. As a result, the potential and real economic growth of the Czech Republic has slowed down considerably, and these factors may also have a negative impact on economic growth in the future.

The main objective of $R \& D$ activities at national and international levels is to produce more results and support the development of economies, which can be achieved by an interaction between the academic environment and the business sphere. To promote such cooperation, technology transfer centers are being developed. In the Czech Republic, such centers were developed with the aid of funds from the EU, Operational Program of OP RaDI, 3 Priority Axis 3.3 Challenge, in the previous programming period. Another challenge is further development of these centers, as experience from abroad, shows the need for these centers on one hand and the issue of their future funding on the other hand. The European interim experience shows the need for a combination of university and grant funding. However, the essential importance of technology transfer centers lies both in cultivating and in setting procedural frameworks for a successful commercialization and a subsequent remuneration for the patent originator. When a research organization does not offer a functional workplace of knowledge transfer, then it is demotivating for a number of researchers. Conversely, a functional workplace of knowledge transfer offering a wide range of quality services will motivate researchers to applying their knowledge and cooperating with the industry sector, which could otherwise discourage them due to its legal and administrative complexity (Žížalová et al., 2011).

Overall, it can be deduced from the findings that a relationship of efficiencies and patent output is influenced by the size of a university. Secondly, there can be observed that technology transfer efficiency contributes more to the patent output that research staff efficiency. This labor market segment is oriented inward and there are also some territorial constraints, despite the fact that the selection of new staff is fully in the hands of individual research institutes. This fact strongly limits the emergence of new incentives not only for research but also for the further development of the institutions themselves. As a consequence, the quality of human resources obtained may also be 
lower, $30-40 \%$ of government and university researcher employees consider the lack of qualified academic staff to be one of the obstacles to research and development in the Czech Republic (Leisyte et al., 2011). Universities should reinforce the quality of human resource development and management in order to maintain the sustainability of institutional quality in the context of current development. Therefore, in the next research the authors will focus on exploring relationships, communication, and interaction in the workplace using the network analysis method. In this way, researchers with higher network reach, frequency of communication, and impact will be identified. This can identify ways to develop research efficiency and collaboration by creating teams and setting up collaboration and contribute to the efficient transfer and sharing of knowledge for further development.

At present, the major challenge for public is to identify not only key areas and research topics. The assessment system of research organizations should support topnotch scientific results and trigger applied research and the involvement of researchers in international cooperation. This means not only a faster implementation of the changes proposed in Methodic 2017 (MŠMT, 2017), but also paying attention to the presentation of this environment as a potential attractive place to draw young researchers.

\section{Abbreviations}

EFA: Exploratory factor analysis; KTE: Knowledge transfer exchange; Ol: Open Innovation; OECD: Organisation for Economic Co-operation and Development; R\&D: Research and development; TTO: Technology transfer offices; WIPO: The World Intellectual Property Organization

\section{Acknowledgements \\ Acknowledgments belong to the reviewers who contributed significantly to the improvement of the article.}

\section{Authors' contributions}

RS collected data and IS analyzed the data; PM and KK wrote the paper. The authors read and approved the final manuscript.

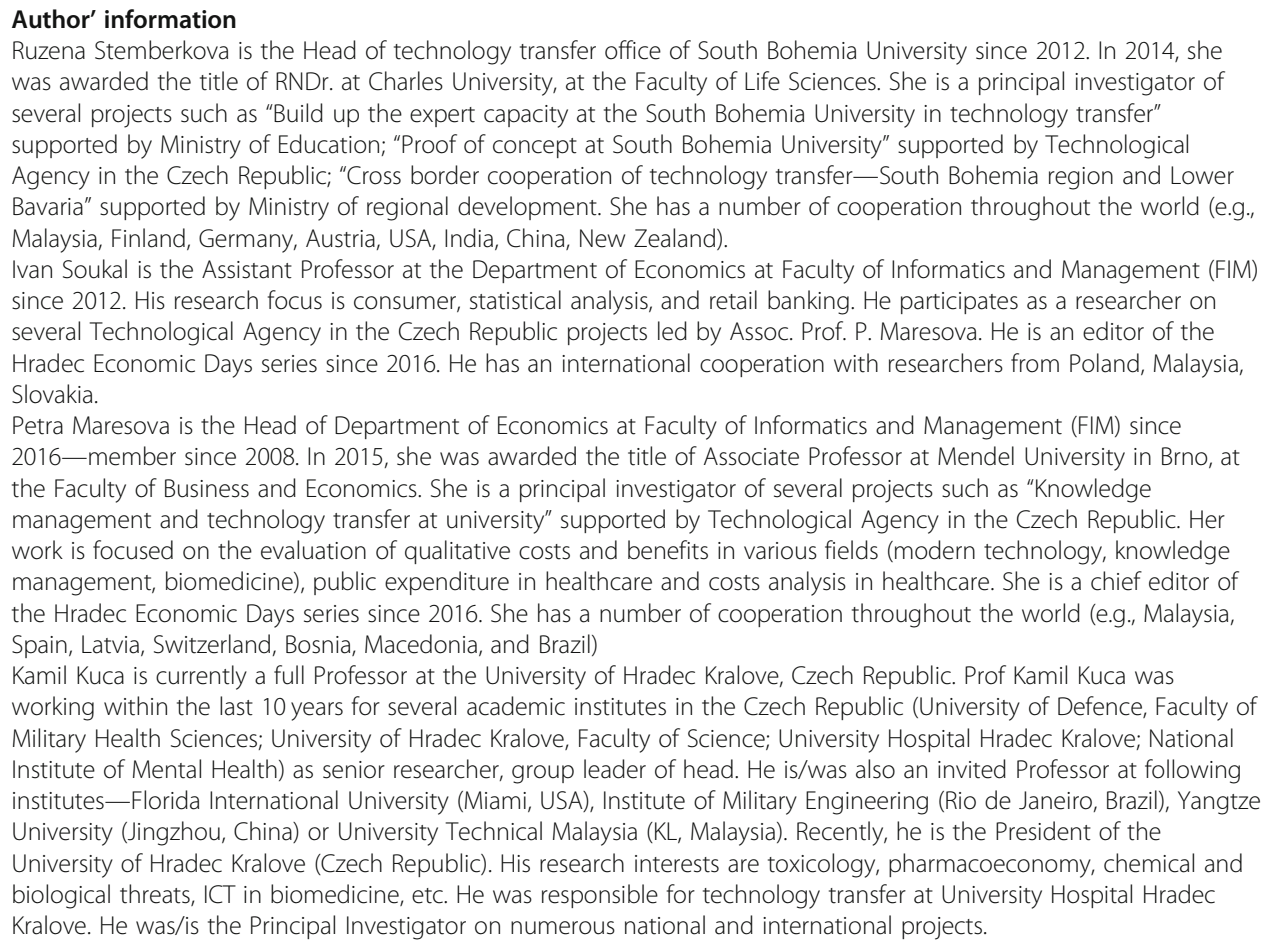




\section{Funding}

The paper is supported by the Technology Agency of the Czech Republic TL02000066 "Effective knowledge transfer management" and SPEV project (2020), investments under the Industry 4.0 concept at the Faculty of Informatics and Management of the University of Hradec Kralove, Czech Republic.

\section{Availability of data and materials}

Mana results are based on available data on the website of each university.

\section{Competing interests}

The authors declare that they have no competing interests.

Received: 25 April 2019 Accepted: 6 March 2020

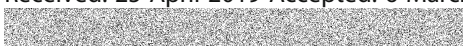

\section{References}

Ambos, T. C., Mäkelä, K., Birkinshaw, J., \& D'Este, P. (2008). When does university research get commercialized? Creating ambidexterity in research institutions. J. Manag. Stud, 45(8), 1424-1447.

Bronzini, P. (2014). The impact of R\&D subsidies on firm innovation. Research Policy, 2016, 45(2), 442-457.

Carayannis, E.G. and Campbell, D.F.J. (2006) 'Introduction and chapter summaries', in Elias, G.C. and Campbell, D.F.J. (Eds.): Knowledge creation, diffusion, and use in innovation networks and knowledge clusters. A comparative systems approach across the United States, Europe and Asia, Praeger, Westport, Connecticut, pp.ix-xxvi.

Chang, Y.-C., Yang, P. Y., \& Chen, M. H. (2009). The determinants of academic research commercial performance, towards an organizational ambidexterity perspective. Res.Policy, 38(6), 936-946.

Chang, Y.C., et al.,2016. Entrepreneurial universities and research ambidexterity: a multilevel analysis. Technovation (2016), 54: 7-21. https://doi.org/10.1016/j.technovation.2016.02.006i

Drumea, C., \& Mirela, B. C. (2015). Competitiveness through innovation for the Romanian economy. Allocations correlated with outputs. Patent applications and their effect on competitiveness. Procedia Economics and Finance, 32, 1541-1549. https://doi.org/10.1016/S2212-5671(15)01544-0.

Etzkowitz, H., \& Leydesdorff, L. (2000). The dynamics of innovation: from National Systems and "Mode 2" to a Triple Helix of University-Industry-Government relations. Research Policy, 29, 109-123 https://doi.org/10.1016/50048-7333(99)00055-4.

Eurostat. Database. 2016. Retrieved September 21, 2017, from http:/ec.europa.eu/eurostat/data/database.

Gür, U., Oylumlu, I. S., \& Kundaya, O. (2017). Critical assessment of entrepreneurial and innovative universities index of Turkey: future directions. Technological Forecasting and Social Change., 123, 161-168.

Clifford M. Hurvich, Chih-Ling Tsai, Regression and time series model selection in small samples, Biometrika, Volume 76, Issue 2, June 1989, Pages 297-307, https://doi.org/10.1093/biomet/76.2.297

Industrial Property Office Czech Republic. 2015. Retrieved September 21, 2017, from https://www.upv.cz/en.html. International Monetary Fund, 2017. Retrieved September 21, 2017, from https:/www.imf.org/en/Countries/CZE

Kang K, Sohn SY. 2016. Evaluating the patenting activities of pharmaceutical research organizations based on new technology indices. Journal of Informetrics. 10(1): 74-81, https://doi.org/10.1016/j.joi.2015.10.006

Kincl, J. (2004). Marketing podle trhü. Praha: Alfa Publishing.

Leisyte, L. (July 2011). University commercialization policies and their implementation in the Netherlands and the United States. Science and Public Policy, 38(6), 437-448.

Likeschová, D., \& Tichá, A. (2013). Multicultural education, creativity and innovation at Universities in the Czech Republic Procedia - Social and Behavioral Sciences., 93, 349-355.

Livotov, P. (2015). Measuring motivation and innovation skills in advanced course in new product development and inventive problem solving with TRIZ for mechanical engineering students. Procedia Engineering, 131, 767-775. https://doi. org/10.1016/j.proeng.2015.12.374.

Lo, S. S. (2012). Innovation and patenting activities at universities in Taiwan: after Bayh-Dole-like acts. World Patent Information. 34(1): 48-53. https://doi.org/10.1016/j.wpi.2011.10.001.

McKinsey. Disruptive technologies: advances that will transform life, business, and the global economy. 2013. Retrieved February 21, 2018, from: https://www.mckinsey.com/ /media/McKinsey/Business\%20Functions/McKinsey\%20Digital/ Our\%20Insights/Disruptive\%20technologies/MGl_Disruptive_technologies_Full_report_May2013.ashx

Melendez, A. P., \& Moreno, A. G. (2012). Open innovation in universities: what motivates researchers to engage in knowledge transfer exchanges? International Journal of Entrepreneurial Behavior \& Research, 18(4), 417-439. https://doi.org/10.1108/ 13552551211239474.

MŠMT. 2017. Hodnocení výzkumných organizací a hodnocení programů účelové podpory výzkumu, vývoje a inovací dle Metodiky M17+.[ Evaluation of research organizations and evaluation of targeted support programs for research, development and innovation according to the M17+methodology] Available at: https:/www.vyzkum.cz/FrontClanek. aspx?idsekce $=799796$

National RIS3 strategy. 2014. Available at: www.vyzkum.cz > FrontClanek.

OECD. 2014. Innovating the public sector: from ideas to impact. Retrieved February 21, 2018, from: https://www.oecd.org/ innovating-the-public-sector/Background-report.pdf

Huggins R, Johnston, A. Knowledge alliances and innovation performance: an empirical perspective on the role of network resources. International Journal of Technology Management. 2012, 57(4):245 - 265

Sanberg, P. S., \& McDevitt, V. L. (2013). Patents: universities profit from products. Nature, 501, 471-472.

UTM, 2019. Available at: https://www.utm.my

WIPO. 2008. Academic patenting: how universities and public research organizations are using their intellectual property to boost research and spur innovative start-ups. . Retrieved February 21, 2018, from: http://www.wipo.int/sme/en/ documents/academic_patenting.html

Wu, Y., Welch, E.W., Huang, W.L. 2015. Commercialization of university inventions: individual and institutional factors affecting licensing of university patents. Technovation.36-37: 12-25 
Zain, S. M., Ab-Rahman, M. S., Ihsan, A. K. A. M., et al. (2011). Motivation for research and publication: experience as a researcher and an academic. Procedia - social and behavioral sciences, 18, 213-219. https://doi.org/10.1016/j.sbspro.2011. 05.030 .

Zdralek, P., Stemberková, R., Matulova, P., Maresova, P., \& Kuca, K. (2016). Patent activity analysis of Czech universities at the industrial property office of Czech Republic. Brno: draft.

Žižalová, P., Čadil, V., \& Pokorný, O. 2011. Knowledge transfer at public universities and public research institutions in the country. Technological Center AV CR. Retrieved September 21, 2016, from https://www.tc.cz/files/istec_news/Transferznalost\%2D\%2DVS-a-WI\%2D\%2D-strategie-realizace-bariery\%2D\%2D2-.pdf.

\section{Publisher's Note}

Springer Nature remains neutral with regard to jurisdictional claims in published maps and institutional affiliations.

Submit your manuscript to a SpringerOpen ${ }^{\odot}$ journal and benefit from:

- Convenient online submission

- Rigorous peer review

- Open access: articles freely available online

- High visibility within the field

- Retaining the copyright to your article

Submit your next manuscript at $\boldsymbol{\nabla}$ springeropen.com 